\title{
Current Trends in the Development of Materials for Bone Grafting and Spinal Fusion (Review)
}

\author{
DOI: $10.17691 / \mathrm{stm} 2018.10 .4 .24$
}

Received July 8, 2018

A.E. Bokov, MD, PhD, Head of the Department of Neurosurgery,

Institute of Traumatology and Orthopedics;

S.G. Mlyavykh, MD, PhD, Head of the Institute of Traumatology and Orthopedics;

N.Y. Shirokova, PhD, Senior Researcher, Department of Pathology and Anatomy;

D.V. Davydenko, PhD, Researcher, Department of Pathology and Anatomy;

N.Y. Orlinskaya, MD, DSc, Professor, Chief Researcher, Head of the Department Pathology and Anatomy

Privolzhsky Research Medical University, 10/1 Minin and Pozharsky Square, Nizhny Novgorod,

603005, Russia

The review addresses the currently used materials for spinal stabilization surgery by spinal fusion. Among them: autografts; allo- and xenografts; materials of synthetic and biological origin; growth factors; multipotent mesenchymal stromal cells; grafts made by 3D modeling. We discuss advantages and disadvantages of these materials as reported in the literature; with this analysis, we hope to stimulate further research into the graft biocompatibility and biointegration, especially into the issue of reparative regeneration and graft transformation into the bone tissue.

Key words: materials for bone grafting; spinal fusion; bone regeneration; replacement of bone defects.

\section{Introduction}

In recent years, the number of musculoskeletal disorders has been increased. In a considerable number of those cases patients can benefit only from surgical interventions applying various types of fusion. Even with the innovative medical technologies, the number of unsuccessful outcomes in these patients remains high because of postoperative pseudo-arthrosis or a failure of the fixation device [1]. The next most common group of diseases that require bone grafting are skeletal injuries, cancer, and musculoskeletal infections [1-3]. Resulting from a pathological process or a traumatic injury, bone defects need to be replaced with appropriate materials to restore the supportability of the damaged segment [1]. Today autologous, allogeneic, and xenogeneic grafts, as well as alternative artificial substitutes, are used in bone grafting surgery.

Bone autoplasty remains the gold standard of treatment, since only autografts have the properties required for the most effective osteointegration $[4,5]$. However, the use of autografts is limited due to the inability to obtain a large amount of autologous material without complications [5]. For example, in patients with osteoporosis, the quality of autografts is not high; and negative consequences of such interventions have been reported [6].

An alternative to bone autoplasty is the use of allogeneic and xenogeneic grafts. Their most obvious shortcomings include the development of a cell- mediated immune rejection or some accidental contamination with infectious agents [5, 7]. In addition, these grafts are not capable of stimulating osteogenesis and osteoinduction [5].

The existing restrictions in using allogeneic and xenogenic grafts arouse an increasing interest in materials of synthetic and biological origin. Some of recently developed materials have a complex internal architecture (imitating the trabecular structure of the cancellous bone); they promote migration, adhesion, proliferation, and differentiation of osteoblast precursors. On the other hand, these materials still need further improvement to ensure the optimal graft osseointegration.

The disadvantages of the bone-substituting materials stimulated the emergence of more ambitious strategies, including bone tissue engineering, combined with cell and growth factors technologies [8-10].

To assess the quality and performance of the implants, imaging modalities (X-ray, CT or MRI) are commonly used. This is primarily due to the fact that samples of the implant and the bone tissue are unavailable for histological examination in clinical studies. Therefore, the imaging techniques provide the major information on bone regeneration around the graft. The imaging, however, is unable to identify the thin connective tissue capsules, which separate the bone tissue from the implant surface, and which prevents implant stability. To assess the nature of osteogenesis and the direction of cell differentiation: e.g., whether it is going through the osteoblast production

Corresponding author: Andrey E. Bokov, e-mail: Andrei_Bokov@mail.ru@mail.ru 
and the formation of new bone tissue, or through the enchondral osteogenesis and the cartilage formation is also impossible by using the imaging techniques only. These processes of osteogenesis are characterized by different periods of regeneration and, undoubtedly, affect the velocity of the structural and functional recovery of the bone, which is of great practical importance [11]. The only reliable method for verifying the developing osseointegration in this case is a morphological study with a morphometric analysis of the bone-implant border but with no separating capsule [12-14].

It takes (on average) 6.6 months for the bone tissue to recover from a defect; this time range may become longer on the background of osteoporosis or endocrine disorder, which seriously compromise the treatment outcome. These arguments further rationalize the search for biocompatible materials that provide for effective reparative regeneration and transformation into the bone tissue.

\section{Autografts}

An ideal osteoplastic material should have the following properties: osteogenicity, osteoinduction, osteoconduction and the ability for osseointegration without forming a boundary capsule around the implant $[5,15]$.

Osteogenicity is the ability to form bone tissue from osteoblasts present in the graft or from progenitors differentiated into osteoblasts.

Osteoinduction - the ability to facilitate the formation of osteoblasts by inducing the differentiation of mesenchymal stem cells and their influx from the tissues of the recipient. Growth factors BMP-2, BMP-7, TGF- $\beta$, IGF, FGF, PDGF have these abilities [16].

Osteoconduction is the ability of a graft to become a resorbable matrix that favors the ingrowth of bone tissue and blood vessels from the graft-donor tissue boundary. These abilities of the graft are eventually manifested in osseointegration, i.e. the graft ingrowth into the surrounding bone tissue without forming a border-line connective tissue capsule; at the end, the graft will be fully incorporated into the bone structure of the recipient [5].

Obviously, only autografts have all the above qualities: they contain osteoblasts, i.e. the precursor cells that promote osteogenesis $[9,17]$. The viable cells remaining in the autograft produce growth factors that stimulate the migration of these precursors, the vascular growth and the formation of a new bone (i.e., osteoinduction). Autografts support the cell and vessel growth and the subsequent restructuring and osteointegration. It is important that auto-bone is perfectly biocompatible and does not cause any immune rejection [18]. Iliac crest, radius, rib, or fibula are most frequently used as autograft sources [19-21].

Yet, autologous bone grafting is not without drawbacks, which limit its use. On the other hand, application of autografts is associated with certain drawbacks that limit the use of the discussed technology. Thus, autograft sampling is a rather traumatic surgical procedure that prolongs the operation time and is associated with the risk of additional complications. Among those reported are long-lasting pain at the donor site, hematomas, pelvic or radial fractures, injury of ilioinguinal nerve and cutaneous nerve of the hip, or the radial nerve, and inflammatory complications [22-24]. During spinal surgery, an autograft may partially lose its mechanical properties or will undergo resorption and migration from the recipient bone which, as a rule, requires later surgical revisions [25]. One of the main disadvantages of autologous bone grafting is the inability to obtain sufficient material to replace large bone defects [17].

\section{Allografts and xenografts}

With the shortcomings of the autologous bone grafting, alternative methods of treatment have been introduced: those involve allografts and xenografts.

Allografts are made of osteoplastic material obtained from the same biological species as the recipient, whereas xenografts are made of bone tissue of a different species [26]. Using these materials in the form of readymade medical products helps resolve the issue of insufficient osteoplastic material for bone substitution [27].

The disadvantage of replacing bone defects with alloand xenografts is the absence of living cells capable of osteogenesis, which makes these materials less osteoinductive [28]. There are additional risks of using these foreign materials for bone tissue replacement. For example, allografts may carry an infectious pathogen; and in the cases of xenografts, such an infection may be as dangerous as prion disease [26, 29-32]. Allografts and xenografts may have foreign antigens in their structure; those can provoke biological incompatibility and transplant rejection [28, 32].

It is known that osteointegration occurs in 5 stages: inflammation, revascularization, osteoinduction (differentiation of polypotent cells into osteoblasts), osteoconduction, and bone remodeling [9, 32]. During the second and third stages, the recipient organism can develop excessive sensitivity to allo- or xenoantigens. In this scenario, it is crucial what type of immune response develops in response to the sensitization: mediated by either Th1 or Th2 lymphocytes [7, 33]. The Th1 lymphocytes produce TNF- $\beta$, IFN- $\gamma$, and IL-2 leading to the activation of macrophages. On the other hand, Th2 lymphocytes produce IL-4, IL-6, and IL-10, which do not activate phagocytosis but promote osseointegration.

Macrophages are classified into $M 1$ and $M 2$ depending on the type of receptors. The M1 macrophages express CD68 and CD80 and produce a large number of pro-inflammatory cytokines (IL-12, TNF) that mediate the inflammation and the subsequent encapsulation separating the implant from the bone tissue. The M2 macrophages express CD163, stimulate Th2 lymphocytes, and produce IL-10 and TGF, thus 
inhibiting the inflammatory response and stimulating bone tissue remodeling [7, 33]. Cytoplasmic proteins and nuclear antigens activate the immune response mediated by M1 macrophages and Th1 lymphocytes. Such an immune response leads to rejection of the bone-substituting material [34, 35].

To avoid graft rejection, various treatments reducing the impact of foreign antigens are used: for example, freezing or freezing with drying [32, 36-38]. There are other more effective ways to eliminate nuclear and cytoplasmic antigens. Triton X-100, EDTA, trypsin, sodium dodecyl sulfate and other reagents have been used to remove the cellular components [39-41]. However, these reagents can adversely affect the mechanical stability of the grafts and thus negatively affect the outcome of spinal fusion, since the support function of the transplant may be compromised [37, 39, 41, 42].

In an attempt to avoid complications associated with allografts, some authors used demineralized bone matrix (DBM); this material contains proteins that stimulate osteogenesis [43, 44]. Bone matrix is obtained by demineralization of bone tissue so that only an insignificant amount of calcified substances remain; this material is rich in type 1 collagen and growth factors [45]. The data on the efficacy of DBM in spinal surgery still vary due to its heterogeneity, especially with regard to the activity of growth factors $[45,46]$. The advantages of DBM are sterility and low antigenicity [47-49]. However, DBM has a number of significant drawbacks: it can be allergic and has a poor mechanical strength. The latter factor does not allow using this material as a supporting implant; instead, DBM is used as an osteogenic additive [44, 50,51].

When replacing large bone defects with various tissue-engineered structures, it is important to ensure proper trophism for adequate osseointegration. This is a critical stage of the entire technology, especially if the bone defect is filled with viable cells: these cells will die without an adequate blood supply. For example, cells located more than 200-500 $\mu \mathrm{m}$ away from the blood microcirculatory bed died during the experiment, and the bone matrix was replaced by fibrous connective tissue [52]. To ensure trophism in the area of bone grafting, an arteriovenous loop consisting of the artificially anastomosed arterial and venous vessels was proposed. This arteriovenous loop placed in the central part of the graft served as a source for axial vascularization, as a result of which a new capillary network was formed (internal vascularization). In combination with peripheral angiogenesis (external vascularization) these capillaries would provide an adequate blood supply and contribute to the survival of the implanted cells [53].

\section{Materials of biological and synthetic origin}

The drawbacks of autologous material, allografts and xenografts stimulated a research into synthetic materials that could become scaffolds for bone tissue replacement.
Specific requirements such as osteoinduction and osteogenesis drew more attention to cell and tissue engineering [5]. In fact, the treatment of xeno- and allografts can be considered tissue engineering as well, but there are more innovative methods of bone tissue processing. The new materials used for this purpose are either biological (for example, collagen) or synthetic. Biological materials made of allo- or xeno-bones are osteoconductive, resorbable by osteoclasts within 4 to 12 months and are gradually replaced with organspecific bone tissue (for allogeneic materials) or coarsefibrous connective tissue (for xenogeneic materials) [54]. For synthetic materials, osteoconductivity and stability of the chemical composition as well as geometric shape, structure, and rate of biological degradation are the major criteria of acceptance [4].

Biological materials. Among the materials of biological origin, collagen, chitosan, and alginate are most often used for bone tissue regeneration. The efficacy of collagen grafts having orderly arranged fibers has been shown together with their ability to proliferate and differentiate into osteoblasts [55]. Currently, collagen-based materials are mainly used as carriers of biologically active molecules capable of osteoinduction $[16,56]$. Notably, grafts consisting solely of collagen lack sufficient strength and can hardly be helpful in bone grafting [5]. Aiming at improving the quality of collagen-based material, experimentation on a collagenelastin composite scaffold has been reported. In this in vitro study, elastin improved not only the mechanical properties of the graft but also stimulated the osteogenic cells differentiation [57]. Other composite materials based on collagen, calcium phosphate and mineralized collagen, resembling the biophysical properties of bone tissue have been studied as well $[58,59]$. To facilitate the delivery of cells and osteoinductive molecules, materials based on cellulose and collagen or collagen and alginate were also proposed [60, 61].

Chitosan is approved for use as a hemostatic material; it is also considered promising for bone grafting. When depolymerized, chitosan produces oligosaccharides with antibacterial effects [62]. The material is stable and maintains its molecular structure at a neutral $\mathrm{pH}$ but gradually degrades at acidic $\mathrm{pH}$ values. Chitosan induces the proliferation of osteoblasts and mesenchymal cells, and also stimulates neovascularization [62]. Due to the positive charge of this polymer, it can effectively bind growth factor molecules that are negatively charged, and then gradually release them in an acidic medium [63]. Composite materials based on chitosan and calcium phosphate have already been created [63]

Osteoplastic materials of biological origin, such as Osteomatrix and Osteoplast, are available in the Russian Federation. Osteomatrix (LLC Konectbiopharm, Russia) is a composition of natural collagen and hydroxyapatite with affinity-bound sulfated glycosaminoglycan (sGAG) [64]. Osteoplast (NPK Vitafarm, Russia) consists of non-demineralized bone collagen of animal origin with 
sGAG [65]. Thanks to the developed manufacturing technology, these biomaterials have collagen and the mineral structures almost fully preserved; it is no less important that they are completely devoid of antigenicity. After these biomaterials or their analogs are implanted in rabbits, an ectopic bone is formed and then colonized with bone marrow cells. Both angio- and osteogenesis are most pronounced with Osteoplast where a rapid maturation of new bone tissue occurs around the implant zone [66].

Synthetic materials. Recost, bioactive glass, polylactide, and polycaprolactone triol are among the most popular synthetic materials. Recost (Ikon Lab $\mathrm{GmbH}$, Russia) consists of a prepolymer, a polyol as a curing agent, and calcium orthophosphate. At its final form, Rekost has a porous microstructure [67]. In experimental studies using Rekost-based bone cement [68], scientists from Kazan found that bone tissue gradually replaced the cement at early stages (7-14 days). Moreover, there was practically neither inflammatory reaction, nor formation of leukocytenecrotic masses, nor traumatic edema. In these conditions, the process of reparative regeneration develops rapidly, as evidenced by the transformation of the connective tissue directly into the bone (after 6 weeks) with no cartilage formation (which often takes place during the bone healing). By week 12, coarsefibrous bone tissue with areas of the lamellar bone was observed in all animals; thus, the experimental defect became completely healed. The above results suggest that the Rekost bone cement is a bioinert and biodegradable regenerative material suitable for reconstructive plastic surgery.

Since their invention in 1986, calcium phosphatebased materials have been widely used for bone tissue augmentation and for osteoplastic surgery. They are easy for handling, perfectly fit the shape of a bone defect, and have excellent biological compatibility [44]. Conversely, the insufficient strength and excessive fragility restrict their implementation in bone replacement procedures. These synthetic materials have found their use as part of composite implants [44, 51]. Composite materials based on collagen and calcium phosphate mimic the mineralized bone matrix. Composite grafts based on synthetic polymers and calcium phosphate stimulate the differentiation of stem cells into osteoblasts, and also promote cell proliferation and synthesis of the bone matrix [69]. $\beta$-tricalcium phosphate ceramics has been used as a bone-replacing material for 25 years and is still considered the gold standard for the artificial bone [70]. This material is bioresorbable, biocompatible, and has good osteoconduction because of its porous structure [44, 71, 72]. The system of interconnected pores supports cellular colonization and accelerates vascularization [41, 73]. The pace of biological degradation is not always predictable; the process of bone resorption by osteoclasts lasts for 13-20 weeks and results in a newly formed bone [74,
75]. Nevertheless, $\beta$-tricalcium phosphate ceramics are inferior of cancellous bone in the mechanical properties, which must be taken into account before their use [47]. The disadvantages of $\beta$-tricalcium phosphate ceramics are partially compensated by the addition of hydroxyapatite. This combination contains two-phase calcium phosphate, which has the advantages of both components: slower resorption and greater mechanical strength (as in hydroxyapatite) and faster growth of a newly formed bone as compared with hydroxyapatite alone [76, 77].

Bioactive glass is a relatively new material, and it is currently approved for use only in dentistry. This material is composed of $45 \%$ silicon oxide, $24.5 \%$ of calcium oxide, $24.5 \%$ of disodium oxide, and $6 \%$ of pyrophosphate [78]. Bioactive glass is characterized by good biological compatibility, but it does not have optimal mechanical properties; therefore, it is most frequently used in combination with collagen and fibrin. Bioactive glass increases the mechanical strength of collagen implants [79]; these materials are osteoinductive and promote the differentiation of mesenchymal stem cells into osteoblasts [80]. In spinal fusion, the efficacy of bioactive glass is not that good as of autografts, but it has an antibacterial effect with the mechanism different from antibacterial drugs [81-83]. In this regard, it is likely that bioactive glass will be in demand for the replacement of bone defects in patients with osteomyelitis, especially on the background of bacterial drug-resistance [81].

Materials based on lactide, polyglycolic acid, and polylactide-co-glycolide are also considered promising options for bone substitution [44, 84]. Polyglycolic acid and polylactide are polymers with a crystalline structure. The copolymerization of these monomers reduces the degree of crystallization, which facilitates hydration and degradation of the polymer. By varying the ratio of monomers or the location of stereoisomers and by changing the molecular mass of the polymer, it is possible to obtain materials with reproducible and controlled parameters of biodegradation that occurs over a few weeks to several months $[4,85,86]$. Lactide is more hydrophobic than polyglycolic acid, and by increasing its content in the polymer one can slow down the pace of degradation. Over the past 30 years, a number of $3 \mathrm{D}$ porous scaffolds based on this polymer have been developed.

Despite the relatively good biocompatibility, polylactide-co-glycolide-based materials have poor osteoconductive properties due to their hydrophobicity, which prevents cell adhesion and proliferation [78] Polylactide-co-glycolide enhances the inflammatory response due to the release of acidic degradation products that can prevent cell colonization [4, 78]. Nevertheless, degradation products of this polymer are identical to natural metabolites and have no cytotoxic effect [4]. In addition, polylactide-co-glycolide grafts have suboptimal mechanical properties, which complicate using these materials if the graft is intended 
to get used for mechanical support. In order to improve the osteoconduction, this material is often used in combination with other biopolymers - collagen, gelatin, or chitosan; also polycaprolactone is added to improve its mechanical properties [84, 87]. Ceramics and bioactive glass are also used for this purpose, besides, biologically active coatings are being developed [84].

Hefty majority of the synthetic materials do not have all the properties required for effective replacement of bone tissue $[4,5,78,79,84,88]$. Their improvement is possible through the development of composite materials. It is known that materials based on calcium phosphate and collagen or calcium phosphate and polylactide-coglycolide have better mechanical properties and more evident osteoconductivity. In addition, the porosity, pore sizes, and their interconnection, the rate of graft degradation and its hydrophilicity also play important roles $[84,89]$. The hydrophobicity makes it difficult for cells to form colonies in the graft; it interferes with the growing blood vessels and the newly formed bone tissue. In spine surgery, the supporting function of the graft is important. The resistance of a human cortical bone varies within 90-230 MPa, while the resistance of spongy bone to compression loads varies from 2 to $90 \mathrm{MPa}$ [89]. As the mechanical strength is insufficient, there is no effective load distribution between the graft and the stabilizing metal implants. Lack of mechanical support may cause an implant failure. On the other hand, an excessive hardness of the fixation device can slow down fusion and cause bone resorption around the graft [90]. The presence of pores provides the necessary osteoconduction and bioresorbability of artificial materials used for bone grafting. In an experiment with calcium phosphate materials, it was shown that macropores with a size of 100-300 $\mu \mathrm{m}$ were the best fit for the growth of bone grafts [5, 89-92]. If the pores are smaller (less than $75 \mu \mathrm{m}$ ), those materials often intergrew with non-mineralized bone tissue or even fibrous bone tissue [89]. Notably, such correlations were not found in an experiment on porous titanium implants [93]; it is, therefore, possible that the optimal pore size is specific for each material and there is no universal optimal value. Materials with interconnected pores have the best properties; such pores favor bone tissue ingrowth [94]. On the other hand, materials with unconnected pores retain osteogenic cells for a longer time and thus facilitate active filling with newly formed bone tissue [89]. The pores contribute to the growth of bone tissue into the graft, but the porous structure of the material weakens its mechanical strength. To develop an effective material, a rational balance between porosity and mechanical strength is required [89].

When manufacturing the synthetic materials for bone grafting, it is important to produce materials with standardized characteristics (porosity, mechanical strength, period of degradation) $[4,5,95]$. In this respect, it is now thought that the standard porosity, standard composition, structure, and mechanical strength can only be achieved using 3D printing. Other previously used methods, such as sponge formation or material foaming are significantly less efficient [95]. Currently, the methods of stereolithography, fusion, selective laser baking and 3D printing are used to produce the bonesubstituting materials with individual characteristics [96-99]. Composite materials based on polymers, bioactive glass, tricalcium phosphate, and collagen have been created and introduced into practice [4]. With all the advantages of composite materials obtained with the additive technologies, the problem of graft vascularization remains unsolved, and therefore it is now proposed to combine these materials with either growth factors or cellular technology products.

\section{Cell technologies}

At the present time, it is obvious that the way to improve osteoinduction and osteogenesis in bonesubstituting materials goes via cell technologies. A key role in the regeneration of bone tissue is assigned to stem cells - a heterogeneous population of cells found in the blood, adipose tissue, umbilical cord blood, and bone marrow [100]. Stem cells migrate to the area of inflammation in response to secreted chemokines, and there participate in the regeneration process [101, 102]. When applied stem cells modulate the immune response so to decrease the secretion of IL-1- $\beta$, IL-6, and TNF- $\alpha$; stem cells do not affect the synthesis of IL-10 or IL-13 [103]. These cells inhibit the immune response (by suppressing the dendritic cells) and the function of natural killer cells so to ultimately reduce the immune response to the implant $[104,105]$. It has been shown that, under hypoxic conditions or in the presence of pro-inflammatory factors in the area of injury, stem cell produce epithelial growth factor (EGF), fibroblast growth factor (FGF), and insulin-like growth factor (IGF), which slow down the cell apoptosis and stimulate neoangiogenesis [106]. The use of stem cells at the site of a fracture simulated in laboratory animals favored the bone callus formation due to increased osteogenesis and chondrogenesis [103]. Stem cells stimulate intramembranous osteogenesis, and also the TGF- $\beta$-induced enchondral ossification of the newly formed bone tissue [102]. Allogeneic stem cells facilitate spinal fusion without causing side effects [107, 108]. Hydroxyapatite and tricalcium phosphate grafts in combination with stem cells have been successfully used in the reconstruction of critical craniofacial defects of the long tubular bone in animals [108-120]. In the majority of countries, cell technologies have not been approved yet for clinical use, and therefore, there are only few reports on successful replacement of bone defect with stem cells in humans [108, 121, 122]

Despite the encouraging results, the question of efficacy and safety of stem cell techniques remains, and so remains uncertainty about possible immune responses to allogeneic stem cells [102]. There is 
evidence that stem cell proliferation may become uncontrollable, and mesenchymal stem cells may become tumorogenic [123]. There are reports on sarcoma formation in the implant-receiving bed, presumably due to the suppression of antitumor immunity [124]. In this regard, studies on the stem cell differentiation into osteogenic or chondrogenic tissues are highly important [96].

\section{Growth factors}

To improve osteoinduction in bone-replacing materials, growth factors have been tested; however, the obtained results are not uniform. In regard to the bone grafting, the following growth factors were studied: bone morphogenetic protein 2 (BMP-2), BMP-7, fibroblast growth factor (FGF), platelet-derived growth factor (PDGF), transforming growth factor beta 3 (TGF- $\beta 3$ ), vascular endothelial growth factor (VEGF), and insulinlike growth factor (IGF) [16].

The bone morphogenetic proteins are multifunctional growth factors, which have a significant effect on the growth, differentiation and apoptosis of various cell types, including osteoblasts, epithelial cells, nerve cells, and chondroblasts $[125,126]$. Also, these proteins accelerate the differentiation of multipotent mesenchymal stromal cells into osteoblasts and chondroblasts, increase the osteocalcin synthesis, accelerate the collagen synthesis, increase the alkaline phosphatase activity, stimulate the synthesis and subsequent mineralization of extracellular matrix [127]. At present, 20 BMP types have been discovered, but only BMP-2, $-4,-6,-7$ have significant osteoinductive properties [128, 129]. In the presence of BMP-2 and BMP-7, osteogenesis is increased by 1.221.0 and 1.1-95.0 times, respectively; yet the optimal concentrations of these growth factors are unknown: the range of doses used in these experiments varied from 5 to $100 \mu \mathrm{g}$ for BMP-2 and from $100 \mu \mathrm{g}$ to $3.5 \mathrm{mg}$ for BMP-7 [16]. It has been found that the action of BMP-2 and BMP-7 is synergistic; upon their combination, osteogenesis is 1.5 times higher than the individual effects of these factors. With the simultaneous use of VEGF and BMP-2, bone tissue regeneration improves, since the first factor stimulates neoangiogenesis, and the second - osteogenic cell differentiation [16]. To date, various materials have been tested as BMP carriers, for example, demineralized bone matrix, collagen sponges, chitosan, gelatin, and hydroxyapatite. The carriers provide not only the delivery of BMP to the site of its action but also the preservation of osteoinducers in this site for a long period of time necessary for the formation of a new bone $[62,129,130]$. When planning a treatment using BMP, the recipient's age should be considered, since it directly affects the biological activity of growth factors. The osteoinductive ability of BMP is reduced at least 2 times in elderly patients, therefore, higher doses are required to cause a noticeable stimulating effect on bone formation [131, 132].
In clinical studies on spinal fusion in the lumbar and cervical spine, the efficacy of recombinant human BMP-2 was superior to that of autografts [133-136]. Nevertheless, the $11 \%$ rate of complications was reported, the occurrence of malignant tumors was $3.4 \%$; in addition to that, immune reactions to BMP-2, cases of renal failure and supraventricular arrhythmias were also observed [137-139]. At present, BMP-2 is recommended for use in spinal surgery to accelerate the formation of the bone block. The clinical evidence for BMP-7 application is inconclusive [140].

Another growth factor - FGF-2 - also aroused some interest due to its potential to stimulate the regeneration of bone tissue. In experiments, his effective dose ranged from 0.01 to $200 \mu \mathrm{g}$ and increased the osteogenesis 1.1-16.4 times in a dose-dependent mode [16]. The putative mechanism of action of FGF-2 is neoangiogenesis and ossification, however, some authors believe that this fibroblast growth factor has a greater effect on chondrogenesis than on osteogenesis $[16,140,141]$. The effect of FGF-2 on osteogenesis is greater than that of FGF-1, but with a constant presence of the factor in the area of osteogenesis, its efficacy decreases. When BMP-2 and FGF-2 are combined, the efficacy of BMP-2 goes down: the fibroblast growth factor inhibits osteogenesis [16].

It is assumed that PDGF can promote regeneration of the bone tissue as a mitogen. It can act as a chemoattractant for stem cells and also stimulate the secretion of growth factors by macrophages [142-144]. PDGF enhances bone regeneration 1.4-2.4 times in the area of an experimental bone defect; the doses used in this case were $0.01-80.0 \mu \mathrm{g}$ [16]. At high doses of PDGF, the bone density in some areas of osteogenesis decreased; also in some cases, no fusion of fractured bones occurred when PDGF and VEGF were combined [16]. With a combination of PDGF and BMP-2, the latter enhanced osteogenesis, presumably this factor is necessary for enchondral ossification [16]. Nevertheless, other data did not confirm the significant effect of PDGF on bone tissue regeneration [145].

TGF- $\beta$ is one of the most important factors of osteogenesis, but its role is ambiguous. As a rule, its action facilitates the formation of cartilage followed by ossification. The effect of TGF- $\beta 3$ alone intensifies osteogenesis by 1.75-3.0 times. Sometimes, the cartilage formation occurs with no increase in bone mass. In the combined use with BMP-2 or stem cells, the efficacy of TGF- $\beta$ increased significantly: these combinations stimulated osteogenesis up to 5 times [16]. It has been shown that TGF- $\beta 1$ enhances the synthesis of mRNA markers in osteoblasts and those of alkaline phosphatase in mouse stem cells, but inhibits the expression of osteocalcin [146, 147]. Its effects depend both on cell density and on the stage of differentiation; the effect is dose-dependent and has a two-phase mode [148-151]. A single exposure to TGF- $\beta 1$ at a dose of $1 \mathrm{ng} / \mathrm{ml}$ triggers the osteoblast differentiation, and a 
second exposure inhibits the differentiation [152, 153]. The inhibition during the second exposure is mainly due to a decrease in the synthesis of IGF-1 [153]. By adding $200 \mathrm{ng} / \mathrm{ml}$ of exogenous IGF-1, the synthesis of alkaline phosphatase in osteoblasts is restored, thus eliminating the suppression caused by TGF- $\beta 1$ [153].

A significant factor of osteoblast differentiation, as well as of bone growth, is IGF-1. It is produced by osteocytes and mature osteoblasts, then deposited in the bone and released as it is resorbed. This cytokine does not cause osteogenic differentiation of stem cells but enhances the function of mature osteoblasts $[153,154]$. IGF-1 is associated with the mechanic transduction in bone tissue [154]: thus, its synthesis goes up as an early response of bone tissue to the mechanical load. Hypersecretion of IGF-1 in transgenic mice leads to increased osteogenesis in response to mechanical stress [155-157]. In the absence of physical load, the addition of IGF-1 does not lead to increased osteogenesis [158, 159]. Damage to the IGF-1 gene in osteoblasts significantly reduces osteogenesis in response to mechanical stress [159]. The significance of this cytokine for bone grafting has been studied in animal experiments; IGF-1, together with PDGF, had a favorable effect on implant integration [160].

There are quite a few papers on using the VEGF cytokines for improving bone regeneration. In bone damage, necrosis and hypoxia are the major pathogenetic factors. VEGF is necessary for the formation of a normal vascular network in areas of tissue damage [161]. With the insertion of VEGF-containing implants in the bone defect, both vascularization and bone mass increased by 1.6-2.0 times [161]. On the other hand, there are reports that only angiogenesis but not bone mass is stimulated [16]. The likely cause of such a discrepancy is the kinetics of VEGF release from the carrier. Slow and prolonged release of VEGF is preferable; otherwise the formation of capillaries outside the vascular bed or the development of angioma during hyper-stimulation is possible [162].

The homologue of VEGF - placental growth factor (PIGF) - is also considered the factor of bone tissue regeneration. There is evidence of its role in four key bone repair processes. First of all, PIGF is necessary for the effective initiation of the inflammatory process and angiogenesis in response to bone damage. Secondly, it enhances the proliferation and differentiation of mesenchymal progenitor cells. Third, it stimulates the formation of cartilage indirectly via the matrix metalloproteinases. Fourth, PIGF is required for optimal remodeling of a newly formed bone [163]. PIGF is also known as an autocrine regulatory factor for stem cells. When secreted at low concentrations $(20 \mathrm{ng} / \mathrm{ml})$, PIGF stimulates the osteogenic differentiation; at higher concentrations $(50 \mathrm{ng} / \mathrm{ml})$, it induces osteoclastogenesis and angiogenesis. Those are the prerequisites for bone remodeling and repair [164]. In vitro studies demonstrated the development of chemotaxis in mesenchymal progenitor cells in response to PIGF [163, 164]. Also, PIGF has been found to significantly enhance the osteoinductive effect of BMP-2 [165].

\section{Perspectives of bone substitute material developments}

Due to the high incidence of traumatic injuries and the prevalence of degenerative and inflammatory musculoskeletal diseases, the importance of bone grafting continues to grow. The above diseases often lead to temporary or permanent disability and negative socio-economic consequences [1, 2, 3, 55]. When replacing a bone defect, autoplasty remains the gold standard of treatment thanks to its optimal osteogenicity, osteoinduction, and osteoconduction, resulting in the best possible osteointegration [5]. With all these advantages, bone autoplasty has its limitations, primarily related to the traumatic procedure of tissue harvesting and the inability to obtain sufficient amount of material to replace large bone defects $[51,166]$. Allografts and xenografts cannot compete with autografts in terms of osteointegration, as they actually represent just bonelike matrices but contain neither growth factors nor living cells $[5,88]$. In addition, using allogeneic and autogenic bones is associated with the risks of transmitting a dangerous infection or an antigen that can provoke an immunogenic graft rejection $[51,88]$.

These factors motivate the search for new solutions. By now, a large number of synthetic and biological materials have been proposed [5]. It is commonly accepted that the ideal material should have sufficient mechanical strength, hydrophilicity, and biological compatibility; besides, osteoinduction and osteogenicity are also important. In fact, none of the existing materials has the optimal combination of these qualities. Therefore, the development of composite grafts capable of combining the best qualities of several materials is considered the way forward [5, 167]. Another problem faced by the manufacturers is the medical need of implants with reproducible and standardized characteristics, such as the rate of biological degradation and the mechanical strength [167]. In addition, it is important to define the standard pore sizes that would enable the ingrowth of blood vessel and newly formed bone tissues [89]. Such materials are expected to be created with the help of additive technologies; and the successful examples of such experiments have been recently reported $[4,5]$.

The physical properties, biodegradability and structure similarity of the existing materials are still insufficient for effective osseointegration. To improve their osteogenicity, cellular technologies based on stem cells have been introduced. According to the obtained results, this line of research is highly promising $[1,5,106,168]$. For example, even a crude aspirate of autologous bone marrow enhanced the osteogenicity of the grafts and accelerated the bone formation [47]. Promising 
results have been obtained with spinal fusion models and experiments on the replacement of bone defects in the cranial vault and long tubular bones. On the other hand, if autologous cells are planned to be used, then additional surgery is required to collect adipose tissue or bone marrow, which may limit this approach. Allogeneic stem cells have been found to be effective in bone tissue regeneration, but the immune response to these cells is the subject of study [102]. The risks of using the stem cell technologies - especially, their tumorigenicity are widely discussed in the literature [123, 124]. An additional factor limiting the use of stem cells is the lack of regulations and a legal framework for their use.

In order to enhance the quality of osteoinduction, cytokines and growth factors have been tested. However, the published data failed to provide consistent evidence on that matter because the reported studies were designed and performed so differently that the results could be hardly compared [16]. It has been found that growth factors and cytokines are involved in multiple processes and their biological activities depend on the dose, the microenvironment and the stage of osteogenesis. A striking example of that notion can be seen from the effects on TGF- $\beta$ and PLGF on osteogenesis [152, 153, 164]. The use of BMP-2 for bone tissue regeneration has been studied better, but there is no unequivocal evidence for its safety. The existing contradictions in the results indicate that we are just beginning the way to tissue technologies.

\section{Conclusion}

It is becoming commonly accepted that only a combination of the additive technologies, their composite biodegradable products, and the cellular and tissue technologies can result in the biologically relevant osteoinduction, osteoconduction, osteogenicity, and supportability. Despite the abundance of research and approaches, the tissue-engineered structures that optimally fit the medical requirements are yet to be found. Nevertheless, the knowledge accumulated in this area suggests that such developments are the most promising ways to reach the ultimate goal — obtaining a graft with tissue regeneration similar to the native bone.

Research funding. The study was supported by the grant "Hybrid organic materials for the synthesis of personalized bone-substituting implants using additive technologies" (project No. 18-13-00434) awarded by the Russian Scientific Foundation.

Conflict of interest. The authors declare no conflicts of interest to be reported.

\section{References}

1. Werner B.C., Li X., Shen F.H. Stem cells in preclinical spine studies. Spine J 2014; 14(3): 542-551, https://doi. org/10.1016/j.spinee.2013.08.031.
2. Amin S., Achenbach S.J., Atkinson E.J., Khosla S., Melton L.J. 3rd. Trends in fracture incidence: a populationbased study over 20 years. J Bone Miner Res 2014; 29(3): 581-589, https://doi.org/10.1002/jbmr.2072.

3. van Vugt T.A., Geurts J., Arts J.J. Clinical application of antimicrobial bone graft substitute in osteomyelitis treatment: a systematic review of different bone graft substitutes available in clinical treatment of osteomyelitis. Biomed Res Int 2016; 2016: 6984656, https://doi.org/10.1155/2016/6984656.

4. Grémare A., Guduric V., Bareille R., Heroguez V., Latour S., L'heureux N., Fricain J.C., Catros S., Le Nihouannen D. Characterization of printed PLA scaffolds for bone tissue engineering. J Biomed Mater Res A 2018; 106(4): 887-894, https://doi.org/10.1002/jbm.a.36289.

5. Oryan A., Alidadi S., Moshiri A., Maffulli N. Bone regenerative medicine: classic options, novel strategies, and future directions. J Orthop Surg Res 2014; 9(1): 18, https://doi. org/10.1186/1749-799X-9-18.

6. Ehrler D.M., Vaccaro A.R. The use of allograft bone in lumbar spine surgery. Clin Orthop Relat Res 2000; 371: 38-45, https://doi.org/10.1097/00003086-200002000-00005.

7. Badylak S.F., Gilbert T.W. Immune response to biologic scaffold materials. Semin Immunol 2008; 20(2): 109-116, https://doi.org/10.1016/j.smim.2007.11.003.

8. Brydone A.S., Meek D., Maclaine S. Bone grafting, orthopaedic biomaterials, and the clinical need for bone engineering. Proc Inst Mech Eng H 2010; 224(12): 1329-1343, https://doi.org/10.1243/09544119jeim770.

9. Athanasiou V.T., Papachristou D.J., Panagopoulos A., Saridis A., Scopa C.D., Megas P. Histological comparison of autograft, allograft-DBM, xenograft, and synthetic grafts in a trabecular bone defect: an experimental study in rabbits. Med Sci Monit 2010; 16(1): BR24-31.

10. Parikh S.N. Bone graft substitutes: past, present, future. J Postgrad Med 2002; 48(2): 142-148.

11. Rerikh V., Avetisyan A., Zaidman A., Lastevsky A., Bataev V., Nikulina A. Experimental osseointegration of hydroxyapatite granules in the lumbar vertebral bodies. Hirurgia pozvonocnika 2013; 4: 43-51, https://doi. org/10.14531/ss2013.4.43-51.

12. Becker S., Maissen O., Ponomarev I., Stoll T., Rahn B., Wilke I. Osteopromotion by a beta-tricalcium phosphate/bone marrow hybrid implant for use in spine surgery. Spine 2006; 31(1): 11-17, https://doi.org/10.1097/01. brs.0000192762.40274.57.

13. Daculsi G., Uzel A.P., Weiss P., Goyenvalle E., Aguado $\mathrm{E}$. Developments in injectable multiphasic biomaterials. The performance of microporous biphasic calcium phosphate granules and hydrogels. J Mater Sci Mater Med 2009; 21(3): 855-861, https://doi.org/10.1007/s10856-009-3914-y.

14. Uchida A., Araki N., Shinto Y., Yoshikawa H., Kurisaki E., Ono K. The use of calcium hydroxyapatite ceramic in bone tumour surgery. J Bone Joint Surg Br 1990; 72(2): 298-302, https://doi.org/10.1302/0301-620x.72b2.2155908.

15. Albrektsson T., Johansson C. Osteoinduction, osteoconduction and osseointegration. Eur Spine J 2001; 10(Suppl 2): S96-S101, https://doi.org/10.1007/s005860100282.

16. Gothard D., Smith E.L., Kanczler J.M., Rashidi H., Qutachi O., Henstock J., Rotherham M., El Haj A., Shakesheff K.M., Oreffo R.O. Tissue engineered bone using select growth factors: a comprehensive review of animal studies and clinical translation studies in man. Eur Cell Mater 2014; 28: 166-207, https://doi.org/10.22203/ecm.v028a13. 
17. Pape H.C., Evans A., Kobbe P. Autologous bone graft: properties and techniques. J Orthop Trauma 2010; 24(Suppl 1): S36-S40, https://doi.org/10.1097/bot.0b013e3181cec4a1.

18. Greenwald A.S., Boden S.D., Goldberg V.M., Khan Y., Laurencin C.T., Rosier R.N.; American Academy of Orthopaedic Surgeons. The Committee on Biological Implants. Bone-graft substitutes: facts, fictions, and applications. J Bone Joint Surg Am 2001; 83-A(Suppl 2 Pt 2): 98-103, https://doi. org/10.2106/00004623-200100022-00007.

19. Mauffrey C., Madsen M., Bowles R.J., Seligson D. Bone graft harvest site options in orthopaedic trauma: a prospective in vivo quantification study. Injury 2012; 43(3): 323-326, https:// doi.org/10.1016/j.injury.2011.08.029.

20. Iyer R.R., Tuite G.F., Meoded A., Carey C.C., Rodriguez L.F. A modified technique for occipitocervical fusion using compressed iliac crest allograft results in a high rate of fusion in the pediatric population. World Neurosurg 2017; 107 : 342-350, https://doi.org/10.1016/j.wneu.2017.07.172.

21. Goyal T., Sankineani S.R., Tripathy S.K. Local distal radius bone graft versus iliac crest bone graft for scaphoid nonunion: a comparative study. Musculoskelet Surg 2013; 97(2): 109-114, https://doi.org/10.1007/s12306-012-0219-y.

22. Ebraheim N.A., Elgafy H., Xu R. Bone-graft harvesting from iliac and fibular donor sites: techniques and complications. J Am Acad Orthop Surg 2001; 9(3): 210-218, https://doi. org/10.5435/00124635-200105000-00007.

23. Kim D.H., Rhim R., Li L., Martha J., Swaim B.H., Banco R.J., Jenis L.G., Tromanhauser S.G. Prospective study of iliac crest bone graft harvest site pain and morbidity. Spine J 2009; 9(11): 886-892, https://doi.org/10.1016/j. spinee.2009.05.006.

24. Christensen B.B. Autologous tissue transplantations for osteochondral repair. Dan Med J 2016; 63(4): B5236.

25. Dimar J.R. $2^{\text {nd }}$, Glassman S.D., Burkus J.K., Pryor P.W., Hardacker J.W., Carreon L.Y. Two-year fusion and clinical outcomes in 224 patients treated with a singlelevel instrumented posterolateral fusion with iliac crest bone graft. Spine J 2009; 9(11): 880-885, https://doi.org/10.1016/j. spinee.2009.03.013.

26. Zamborsky R., Svec A., Bohac M., Kilian M., Kokavec M. Infection in bone allograft transplants. Exp Clin Transplant 2016; 14(5): 484-490.

27. Müller M.A., Frank A., Briel M., Valderrabano V., Vavken P., Entezari V., Mehrkens A. Substitutes of structural and non-structural autologous bone grafts in hindfoot arthrodeses and osteotomies: a systematic review. BMC Musculoskelet Disord 2013; 14(1): 59, https://doi. org/10.1186/1471-2474-14-59.

28. Smith C.A., Richardson S.M., Eagle M.J., Rooney P., Board T., Hoyland J.A. The use of a novel bone allograft wash process to generate a biocompatible, mechanically stable and osteoinductive biological scaffold for use in bone tissue engineering. J Tissue Eng Regen Med 2015; 9(5): 595-604, https://doi.org/10.1002/term.1934.

29. Kim Y., Rodriguez A.E., Nowzari H. The risk of prion infection through bovine grafting materials. Clin Implant Dent Relat Res 2016; 18(6): 1095-1102, https://doi.org/10.1111/ cid.12391.

30. Mirabet V., Álvarez M., Luis-Hidalgo M., Galán J., Puig N., Larrea L., Arbona C. Detection of hepatitis B virus in bone allografts from donors with occult hepatitis $B$ infection. Cell Tissue Bank 2017; 18(3): 335-341, https://doi. org/10.1007/s10561-017-9644-3.
31. Ward W.G., Heise E., Boles C., Kiger D., Gautreaux M., Rushing J., Smith B.P., Bullard D. Human leukocyte antigen sensitization after structural cortical allograft implantations. Clin Orthop Relat Res 2005; 435: 31-35, https://doi.org/10.1097/01. blo.0000165848.43820.98.

32. Gomes K.U., Carlini J.L., Biron C., Rapoport A., Dedivitis R.A. Use of allogeneic bone graft in maxillary reconstruction for installation of dental implants. J Oral Maxillofac Surg 2008; 66(11): 2335-2338, https://doi. org/10.1016/j.joms.2008.06.006.

33. Allman A., McPherson T., Badylak S., Merrill L., Kallakury B., Sheehan C., Raeder R., Metzger D. Xenogeneic extracellular matrix grafts elicit a TH2-restricted immune response. Transplantation 2001; 71(11): 1631-1640, https:// doi.org/10.1097/00007890-200106150-00024.

34. Brown B.N., Valentin J.E., Stewart-Akers A.M., McCabe G.P., Badylak S.F. Macrophage phenotype and remodeling outcomes in response to biologic scaffolds with and without a cellular component. Biomaterials 2009; 30(8): 1482-1491, https://doi.org/10.1016/j.biomaterials.2008.11.040.

35. Valentin J.E., Stewart-Akers A.M., Gilbert T.W., Badylak S.F. Macrophage participation in the degradation and remodeling of extracellular matrix scaffolds. Tissue Eng Part A 2009; 15(7): 1687-1694, https://doi.org/10.1089/ten. tea.2008.0419.

36. Keating J.F., McQueen M.M. Substitutes for autologous bone graft in orthopaedic trauma. $J$ Bone Joint Surg $\mathrm{Br} 2001 ; 8$ 3(1): 3-8, https://doi.org/10.1302/0301-620x.83b1.11952.

37. Malinin T., Temple H.T. Comparison of frozen and freeze-dried particulate bone allografts. Cryobiology 2007; 55(2): 167-170, https://doi.org/10.1016/j.cryobiol.2007.05.007.

38. Kurien T., Pearson R.G., Scammell B.E. Bone graft substitutes currently available in orthopaedic practice: the evidence for their use. Bone Joint J 2013; 95-B(5): 583-597, https://doi.org/10.1302/0301-620x.95b5.30286.

39. Elder B.D., Eleswarapu S.V., Athanasiou K.A. Extraction techniques for the decellularization of tissue engineered articular cartilage constructs. Biomaterials 2009; 30(22): 3749 3756, https://doi.org/10.1016/j.biomaterials.2009.03.050.

40. Vavken P., Joshi S., Murray M.M. TRITON-X is most effective among three decellularization agents for ACL tissue engineering. J Orthop Res 2009; 27(12): 1612-1618, https:// doi.org/10.1002/jor.20932.

41. Gui L., Chan S.A., Breuer C.K., Niklason L.E. Novel utilization of serum in tissue decellularization. Tissue Eng Part C Methods 2010; 16(2): 173-184, https://doi.org/10.1089/ten. tec.2009.0120.

42. Fölsch C., Mittelmeier W., Bilderbeek U., Timmesfeld N., von Garrel T., Matter P.H. Effect of storage temperature on allograft bone. Transfus Med Hemother 2012; 39(1): 36-40, https://doi.org/10.1159/000335647.

43. Sandhu H.S., Khan S.N., Suh D.Y., Boden S.D. Demineralized bone matrix, bone morphogenetic proteins, and animal models of spine fusion: an overview. Eur Spine $J$ 2001; 10(Suppl 2): S122-S131, https://doi.org/10.1007/ s005860100303.

44. Fernandez de Grado G., Keller L., Idoux-Gillet Y., Wagner Q., Musset A.M., Benkirane-Jessel N., Bornert F., Offner D. Bone substitutes: a review of their characteristics, clinical use, and perspectives for large bone defects management. J Tissue Eng 2018; 9: 2041731418776819, https://doi.org/10.1177/2041731418776819.

45. Miyazaki M., Tsumura H., Wang J.C., Alanay A. An 
update on bone substitutes for spinal fusion. Eur Spine J 2009; 18(6): 783-799, https://doi.org/10.1007/s00586-009-0924-x.

46. Buser Z., Brodke D.S., Youssef J.A., Rometsch E., Park J.B., Yoon S.T., Wang J.C., Meisel H.J. Allograft versus demineralized bone matrix in instrumented and noninstrumented lumbar fusion: a systematic review. Global Spine J 2018; 8(4): 396-412, https://doi.org/ $10.1177 / 2192568217735342$.

47. Cornell C.N., Lane J.M. Current understanding of osteoconduction in bone regeneration. Clin Orthop Relat Res 1998; 355(Suppl): S267-S273, https://doi.org/10. 1097/00003086-199810001-00027.

48. Kirilova I.A. Demineralized bone graft as an osteogenesis stimulator: current literature review. Hirurgia pozvonocnika 2004; 3: $105-110$.

49. Ivchenko V.K., Fadeev G., Pikaliuk V.S., Opalinskaia L. The stimulation of reparative regeneration with demineralized bone matrix in puncture osteoplasty operations for bone cysts in children. Vestnik hirurgii im. I.I. Grekova 1994; 153(7-12): 83-86.

50. Kinney R.C., Ziran B.H., Hirshorn K., Schlatterer D., Ganey T. Demineralized bone matrix for fracture healing: fact or fiction? J Orthop Trauma 2010; 24(Suppl 1): S52-S55, https://doi.org/10.1097/bot.0b013e3181d07ffa.

51. Campana V., Milano G., Pagano E., Barba M., Cicione C., Salonna G., Lattanzi W., Logroscino G. Bone substitutes in orthopaedic surgery: from basic science to clinical practice. J Mater Sci Mater Med 2014; 25(10): 24452461, https://doi.org/10.1007/s10856-014-5240-2.

52. Folkman J., Hochberg M. Self-regulation of growth in three dimensions. J Exp Med 1973; 138(4): 745-753, https:// doi.org/10.1084/jem.138.4.745.

53. Lokmic Z., Stillaert F., Morrison W.A., Thompson E.W., Mitchell G.M. An arteriovenous loop in a protected space generates a permanent, highly vascular, tissue-engineered construct. FASEB J 2007; 21(2): 511-522, https://doi. org/10.1096/fj.06-6614com.

54. Bigham A.S., Dehghani S.N., Shafiei Z., Torabi Nezhad S. Xenogenic demineralized bone matrix and fresh autogenous cortical bone effects on experimental bone healing: radiological, histopathological and biomechanical evaluation. J Orthop Traumatol 2008; 9(2): 73-80, https://doi. org/10.1007/s10195-008-0006-6.

55. Pastorino L., Dellacasa E., Scaglione S., Giulianelli M., Sbrana F., Vassalli M., Ruggiero C. Oriented collagen nanocoatings for tissue engineering. Colloids Surf $B$ Biointerfaces 2014; 114: 372-378, https://doi.org/10.1016/j. colsurfb.2013.10.026.

56. Hamilton P.T., Jansen M.S., Ganesan S., Benson R.E., Hyde-Deruyscher R., Beyer W.F., Gile J.C., Nair S.A., Hodges J.A., Grøn H. Improved bone morphogenetic protein-2 retention in an injectable collagen matrix using bifunctional peptides. PLoS One 2013; 8(8): e70715, https://doi. org/10.1371/journal.pone.0070715.

57. Amruthwar S.S., Janorkar A.V. In vitro evaluation of elastin-like polypeptide-collagen composite scaffold for bone tissue engineering. Dent Mater 2013; 29(2): 211-220, https:// doi.org/10.1016/j.dental.2012.10.003.

58. Thula T.T., Rodriguez D.E., Lee M.H., Pendi L., Podschun J., Gower L.B. In vitro mineralization of dense collagen substrates: a biomimetic approach toward the development of bone-graft materials. Acta Biomater 2011; 7(8): 3158-3169, https://doi.org/10.1016/j.actbio.2011.04.014.
59. Inzana J.A., Olvera D., Fuller S.M., Kelly J.P., Graeve O.A., Schwarz E.M., Kates S.L., Awad H.A. 3D printing of composite calcium phosphate and collagen scaffolds for bone regeneration. Biomaterials 2014; 35(13): 4026-4034, https://doi.org/10.1016/j.biomaterials.2014.01.064.

60. Perez R.A., Kim M., Kim T.H., Kim J.H., Lee J.H., Park J.H., Knowles J.C., Kim H.W. Utilizing core-shell fibrous collagen-alginate hydrogel cell delivery system for bone tissue engineering. Tissue Eng Part A 2014; 20(1-2): 103-114, https://doi.org/10.1089/ten.tea.2013.0198.

61. Aravamudhan A., Ramos D.M., Nip J., Harmon M.D., James R., Deng M., Laurencin C.T., Yu X., Kumbar S.G. Cellulose and collagen derived micro-nano structured scaffolds for bone tissue engineering. J Biomed Nanotechnol 2013; 9(4): 719-731, https://doi.org/10.1166/jbn.2013.1574.

62. LogithKumar R., KeshavNarayan A., Dhivya S., Chawla A., Saravanan S., Selvamurugan N. A review of chitosan and its derivatives in bone tissue engineering. Carbohydr Polym 2016; 151: 172-188, https://doi. org/10.1016/j.carbpol.2016.05.049.

63. Venkatesan J., Anil S., Kim S.K., Shim M.S. Chitosan as a vehicle for growth factor delivery: various preparations and their applications in bone tissue regeneration. Int $J$ Biol Macromol 2017; 104(Pt B): 1383-1397, https://doi. org/10.1016/j.ijbiomac.2017.01.072.

64. Lekishvili M.V., Balberkin A.V., Kolondaev A.F., Vasil'ev M.G., Baranetskiy A.L., Buklemishev Yu.V. The first experience of using the Osteomatrix biocomposite material in the bone pathology clinic. Vestnik travmatologii $i$ ortopedii im. N.N. Priorova 2002; 4: 80-83.

65. Dunaev M.V., Kitaev V.A., Matavkina M.V., Druzhinin A.E., Bubnov A.S. Comparative analysis and clinical experience with osteoplastic materials materials based on non-demineralized bone collagen and artificial hydroxylapatite at the close of bone defects in ambulatory surgical dentistry. Vestnik Rossiiskoi akademii meditsinskikh nauk 2014; 69(7-8): 112-120, https://doi.org/10.15690/ vramn.v69i7-8.1117.

66. Sirak S.V., Kazieva I.E., Martirosyan A.K. Clinical and experimental use osteoplastic materials combined with electromagnetic radiation to speed up the regeneration of bone defects jaw. Fundamental'nye issledovaniya 2013; 5-2: 389-393.

67. Krasnozhen V.N., Pokrovskaya E.M., Mikhalin A.N. The clinical rationale for the use of polymeric implant in the reconstruction of bone defects of the paranasal sinuses. Rossiyskaya rinologiya 2013; 21(2): 12-13.

68. Pokrovskaya E.M. Using the polymeric implants in reconstructive surgery of paranasal sinuses (experimental research). Izvestiya Samarskogo nauchnogo tsentra Rossiyskoy akademii nauk. Sotsial'nye, gumanitarnye, medikobiologicheskie nauki 2014; 16(5-4): 1415-1417.

69. Patlolla A., Arinzeh T.L. Evaluating apatite formation and osteogenic activity of electrospun composites for bone tissue engineering. Biotechnol Bioeng 2014; 111(5): 1000 1017, https://doi.org/10.1002/bit.25146.

70. Galois L., Mainard D., Delagoutte J.P. Beta-tricalcium phosphate ceramic as a bone substitute in orthopaedic surgery. Int Orthop 2002; 26(2): 109-115, https://doi.org/10.1007/ s00264-001-0329-x.

71. Gaasbeek R.D., Toonen H.G., van Heerwaarden R.J., Buma P. Mechanism of bone incorporation of betaTCP bone substitute in open wedge tibial osteotomy in 
patients. Biomaterials 2005; 26(33): 6713-6719, https://doi. org/10.1016/j.biomaterials.2005.04.056.

72. Koerten H.K., van der Meulen J. Degradation of calcium phosphate ceramics. J Biomed Mater Res 1999; 44(1): 78-86, https://doi.org/10.1002/(sici)1097-4636(199901)44:1<78::aidjbm9>3.0.co;2-6.

73. Malhotra A., Habibovic P. Calcium phosphates and angiogenesis: implications and advances for bone regeneration. Trends Biotechnol 2016; 34(12): 983-992, https://doi.org/10.1016/j.tibtech.2016.07.005.

74. Bohner M. Calcium orthophosphates in medicine: from ceramics to calcium phosphate cements. Injury 2000; 31(Suppl 4): 37-47, https://doi.org/10.1016/s00201383(00)80022-4.

75. Chazono M., Tanaka T., Komaki H., Fujii K. Bone formation and bioresorption after implantation of injectable beta-tricalcium phosphate granules-hyaluronate complex in rabbit bone defects. J Biomed Mater Res A 2004; 70(4): 542549, https://doi.org/10.1002/jbm.a.30094.

76. Spivak J.M., Hasharoni A. Use of hydroxyapatite in spine surgery. Eur Spine J 2001; 10(Suppl 2): S197-S204, https://doi.org/10.1007/s005860100286.

77. Bansal R., Patil S., Chaubey K.K., Thakur R.K., Goyel P. Clinical evaluation of hydroxyapatite and $\beta$-tricalcium phosphate composite graft in the treatment of intrabony periodontal defect: a clinico-radiographic study. J Indian Soc Periodontol 2014; 18(5): 610-617, https://doi. org/10.4103/0972-124x.142455.

78. Rahaman M.N., Day D.E., Bal B.S., Fu Q., Jung S.B., Bonewald L.F., Tomsia A.P. Bioactive glass in tissue engineering. Acta Biomater 2011; 7(6): 2355-2373, https://doi. org/10.1016/j.actbio.2011.03.016.

79. El-Fiqi A., Lee J.H., Lee E.J., Kim H.W. Collagen hydrogels incorporated with surface-aminated mesoporous nanobioactive glass: improvement of physicochemical stability and mechanical properties is effective for hard tissue engineering. Acta Biomater 2013; 9(12): 9508-9521, https:// doi.org/10.1016/j.actbio.2013.07.036.

80. Silva A.R., Paula A.C., Martins T.M., Goes A.M., Pereria M.M. Synergistic effect between bioactive glass foam and a perfusion bioreactor on osteogenic differentiation of human adipose stem cells. J Biomed Mater Res A 2014; 102(3): 818-827, https://doi.org/10.1002/jbm.a.34758.

81. van Gestel N.A., Geurts J., Hulsen D.J., van Rietbergen B., Hofmann S., Arts J.J. Clinical applications of S53P4 bioactive glass in bone healing and osteomyelitic treatment: a literature review. Biomed Res Int 2015; 2015: 684826, https://doi.org/10.1155/2015/684826.

82. Leppäranta O., Vaahtio M., Peltola T., Zhang D., Hupa L., Hupa M., Ylänen H., Salonen J.I., Viljanen M.K., Eerola E. Antibacterial effect of bioactive glasses on clinically important anaerobic bacteria in vitro. J Mater Sci Mater Med 2008; 19(2): 547-551, https://doi.org/10.1007/s10856-007-3018-5.

83. Zhang D., Leppäranta O., Munukka E., Ylänen H., Viljanen M.K., Eerola E., Hupa M., Hupa L. Antibacterial effects and dissolution behavior of six bioactive glasses. $J$ Biomed Mater Res A 2010; 93(2): 475-483, https://doi.org/10.1002/ jbm.a.32564.

84. Félix Lanao R.P., Jonker A.M., Wolke J.G., Jansen J.A., van Hest J.C., Leeuwenburgh S.C. Physicochemical properties and applications of poly(lactic-co-glycolic acid) for use in bone regeneration. Tissue Eng Part B Rev 2013; 19(4): 380-390, https://doi.org/10.1089/ten.teb.2012.0443.
85. Yoshioka T., Kawazoe N., Tateishi T., Chen G. In vitro evaluation of biodegradation of poly (lactic-co-glycolic acid) sponges. Biomaterials 2008; 29(24-25): 3438-3443, https:// doi.org/10.1016/j.biomaterials.2008.04.011.

86. Félix Lanao R.P., Leeuwenburgh S.C., Wolke J.G., Jansen J.A. In vitro degradation rate of apatitic calcium phosphate cement with incorporated PLGA microspheres. Acta Biomater 2011; 7(9): 3459-3468, https://doi.org/10.1016/j. actbio.2011.05.036.

87. Wang J., Yu X. Preparation, characterization and in vitro analysis of novel structured nanofibrous scaffolds for bone tissue engineering. Acta Biomater 2010; 6(8): 3004-3012, https://doi.org/10.1016/j.actbio.2010.01.045.

88. Polo-Corrales L., Latorre-Esteves M., Ramirez-Vick J.E. Scaffold design for bone regeneration. J Nanosci Nanotechnol 2014; 14(1): 15-56, https://doi.org/10.1166/jnn.2014.9127.

89. Hannink G., Arts J.J. Bioresorbability, porosity and mechanical strength of bone substitutes: what is optimal for bone regeneration? Injury 2011; 42(Suppl 2): S22-S25, https:// doi.org/10.1016/j.injury.2011.06.008.

90. Neman J., Hambrecht A., Cadry C., Jandial R. Stem cell-mediated osteogenesis: therapeutic potential for bone tissue engineering. Biologics 2012; 6: 47-57, https://doi. org/10.2147/btt.s22407.

91. Karageorgiou V., Kaplan D. Porosity of 3D biomaterial scaffolds and osteogenesis. Biomaterials 2005; 26(27): 54745491, https://doi.org/10.1016/j.biomaterials.2005.02.002.

92. Tsuruga E., Takita H., Itoh H., Wakisaka Y., Kuboki Y. Pore size of porous hydroxyapatite as the cell-substratum controls BMP-induced osteogenesis. J Biochem 1997; 121(2): 317-324, https://doi.org/10.1093/oxfordjournals.jbchem.a021589.

93. Itälä A.I., Ylänen H.O., Ekholm C., Karlsson K.H., Aro H.T. Pore diameter of more than 100 micron is not requisite for bone ingrowth in rabbits. J Biomed Mater Res 2001; 58(6): 679-683, https://doi.org/10.1002/jbm.1069.

94. Blokhuis T.J., Termaat M.F., den Boer F.C., Patka P., Bakker F.C., Haarman H.J. Properties of calcium phosphate ceramics in relation to their in vivo behavior. J Trauma 2000; 48(1): 179-186, https://doi.org/10.1097/00005373-20000100000037.

95. Qi X., Pei P., Zhu M., Du X., Xin C., Zhao S., Li X., Zhu Y. Three dimensional printing of calcium sulfate and mesoporous bioactive glass scaffolds for improving bone regeneration in vitro and in vivo. Sci Rep 2017; 7(1): 42556, https://doi.org/10.1038/srep42556.

96. Lee J.W., Kang K.S., Lee S.H., Kim J.Y., Lee B.K., Cho D.W. Bone regeneration using a microstereolithographyproduced customized poly(propylene fumarate)/diethyl fumarate photopolymer 3D scaffold incorporating BMP-2 loaded PLGA microspheres. Biomaterials 2011; 32(3): 744752, https://doi.org/10.1016/j.biomaterials.2010.09.035.

97. Wiria F.E., Leong K.F., Chua C.K., Liu Y. Poly-epsiloncaprolactone/hydroxyapatite for tissue engineering scaffold fabrication via selective laser sintering. Acta Biomater 2007; 3(1): 1-12, https://doi.org/10.1016/j.actbio.2006.07.008.

98. Fielding G.A., Bandyopadhyay A., Bose S. Effects of silica and zinc oxide doping on mechanical and biological properties of 3D printed tricalcium phosphate tissue engineering scaffolds. Dent Mater 2012; 28(2): 113-122, https://doi.org/10.1016/j.dental.2011.09.010.

99. Park S.A., Lee S.H., Kim W.D. Fabrication of porous polycaprolactone/hydroxyapatite (PCL/HA) blend scaffolds using a 3D plotting system for bone tissue engineering. 
Bioprocess Biosyst Eng 2011; 34(4): 505-513, https://doi. org/10.1007/s00449-010-0499-2.

100. Lieder R., Sigurjonsson O.E. The effect of recombinant human interleukin-6 on osteogenic differentiation and YKL-40 expression in human, bone marrow-derived mesenchymal stem cells. Biores Open Access 2014; 3(1): 29 34, https://doi.org/10.1089/biores.2013.0035.

101. Bueno E.M., Glowacki J. Cell-free and cell-based approaches for bone regeneration. Nat Rev Rheumatol 2009; 5(12): 685-697, https://doi.org/10.1038/nrrheum.2009.228.

102. Kiernan C.H., Wolvius E.B., Brama P.A.J., Farrell E. The immune response to allogeneic differentiated mesenchymal stem cells in the context of bone tissue engineering. Tissue Eng Part B Rev 2018; 24(1): 75-83, https://doi.org/10.1089/ten.teb.2017.0175.

103. Granero-Moltó F., Weis J.A., Miga M.I., Landis B., Myers T.J., O'Rear L., Longobardi L., Jansen E.D., Mortlock D.P., Spagnoli A. Regenerative effects of transplanted mesenchymal stem cells in fracture healing. Stem Cells 2009; 27(8): 1887-1898, https://doi.org/10.1002/stem.103.

104. Bartholomew A., Polchert D., Szilagyi E., Douglas G.W., Kenyon N. Mesenchymal stem cells in the induction of transplantation tolerance. Transplantation 2009; 87 (9 Suppl): S55-S57, https://doi.org/10.1097/ tp.0b013e3181a287e6.

105. Le Blanc K., Frassoni F., Ball L., Locatelli F., Roelofs H., Lewis I., Lanino E., Sundberg B., Bernardo M.E., Remberger M., Dini G., Egeler R.M., Bacigalupo A., Fibbe W., Ringdén O.; Developmental Committee of the European Group for Blood and Marrow Transplantation. Mesenchymal stem cells for treatment of steroid-resistant, severe, acute graft-versus-host disease: a phase II study. Lancet 2008; 371(9624): 1579-1586, https://doi.org/10.1016/s0140-6736 (08)60690-x.

106. Qin Y., Guan J., Zhang C. Mesenchymal stem cells: mechanisms and role in bone regeneration. Postgrad Med J 2014; 90(1069): 643-647, https://doi.org/10.1136/ postgradmedj-2013-132387.

107. Tang Z.B., Cao J.K., Wen N., Wang H.B., Zhang Z.W., Liu Z.Q., Zhou J., Duan C.M., Cui F.Z., Wang C.Y. Posterolateral spinal fusion with nano-hydroxyapatite-collagen/ PLA composite and autologous adipose-derived mesenchymal stem cells in a rabbit model. J Tissue Eng Regen Med 2012; 6(4): 325-336, https://doi.org/10.1002/term.445.

108. Lee T.H., Huang Y.H., Chang N.K., Lin W.C., Chien P.W., Su T.M., Hsieh D.J., Lee T.C. Characterization and spinal fusion effect of rabbit mesenchymal stem cells. BMC Res Notes 2013; 6(1): 528, https://doi.org/10.1186/1756-05006-528.

109. Liu G., Zhao L., Zhang W., Cui L., Liu W., Cao Y. Repair of goat tibial defects with bone marrow stromal cells and beta-tricalcium phosphate. J Mater Sci Mater Med 2008; 19(6): 2367-2376, https://doi.org/10.1007/s10856-007-3348-3.

110. Giannoni P., Mastrogiacomo M., Alini M. Pearce S.G., Corsi A., Santolini F., Muraglia A., Bianco P., Cancedda R. Regeneration of large bone defects in sheep using bone marrow stromal cells. J Tissue Eng Regen Med 2008; 2(5): 253-262, https://doi.org/10.1002/term.90.

111. Dumas A., Moreau M.F., Ghérardi R.K., Baslé M.F., Chappard D. Bone grafts cultured with bone marrow stromal cells for the repair of critical bone defects: an experimental study in mice. J Biomed Mater Res A 2009; 90(4): 1218-1229, https://doi.org/10.1002/jbm.a.32176.
112. Xu J.Z., Qin H., Wang X.Q., Zhou Q., Luo F., Hou T.Y., He Q.Y. Repair of large segmental bone defects using bone marrow stromal cells with demineralized bone matrix. Orthop Surg 2009; 1(1): 34-41, https://doi.org/10.1111/ j.2757-7861.2008.00007.x.

113. Nair M.B., Varma H.K., Menon K.V., Shenoy S.J., John A. Reconstruction of goat femur segmental defects using triphasic ceramic-coated hydroxyapatite in combination with autologous cells and platelet-rich plasma. Acta Biomater 2009; 5(5): 1742-1755, https://doi.org/10.1016/j.actbio.2009.01.009.

114. Chang S.C., Lin T.M., Chung H.Y., Chen P.K., Lin F.H., Lou J., Jeng L.B. Large-scale bicortical skull bone regeneration using ex vivo replication-defective adenoviralmediated bone morphogenetic protein-2 gene-transferred bone marrow stromal cells and composite biomaterials. Neurosurgery 2009; 65(6 Suppl): 75-81, https://doi. org/10.1227/01.neu.0000345947.33730.91.

115. Chang S.C., Chung H.Y., Tai C.L., Chen P.K., Lin T.M., Jeng L.B. Repair of large cranial defects by hBMP2 expressing bone marrow stromal cells: comparison between alginate and collagen type I systems. J Biomed Mater Res A 2010; 94(2): 433-441, https://doi.org/10.1002/jbm.a.32685.

116. Xiao C., Zhou H., Ge S., Tang T., Hou H., Luo M., Fan X. Repair of orbital wall defects using biocoral scaffolds combined with bone marrow stem cells enhanced by human bone morphogenetic protein-2 in a canine model. Int $J$ Mol Med 2010; 26(4): 517-525, https://doi.org/10.3892/ ijmm_00000494.

117. Zhou H., Deng Y., Bi X., Xiao C., Wang Y., Sun J., Gu P., Fan X. Orbital wall repair in canines with beta-tricalcium phosphate and induced bone marrow stromal cells. J Biomed Mater Res B Appl Biomater 2013; 101(8): 1340-1349, https:// doi.org/10.1002/jbm.b.32951.

118. Gardel L., Afonso M., Frias C., Gomes M., Reis R. Assessing the repair of critical size bone defects performed in a goat tibia model using tissue-engineered constructs cultured in a bidirectional flow perfusion bioreactor. J Biomater Appl 2014 29(2): 172-185, https://doi.org/10.1177/0885328213519351.

119. Fernandes M.B., Guimarães J.A., Casado P.L., Cavalcanti Ados S., Gonçalves N.N., Ambrósio C.E., Rodrigues F., Pinto A.C., Miglino M.A., Duarte M.E. The effect of bone allografts combined with bone marrow stromal cells on the healing of segmental bone defects in a sheep model. BMC Vet Res 2014; 10(1): 36, https://doi.org/10.1186/17466148-10-36.

120. Ronca A., Guarino V., Raucci M.G., Salamanna F., Martini L., Zeppetelli S., Fini M., Kon E., Filardo G., Marcacci M., Ambrosio L. Large defect-tailored composite scaffolds for in vivo bone regeneration. J Biomater Appl 2014; 29(5): 715-727, https://doi.org/10.1177/0885328214539823.

121. Quarto R., Mastrogiacomo M., Cancedda R., Kutepov S.M., Mukhachev V., Lavroukov A., Kon E., Marcacci M. Repair of large bone defects with the use of autologous bone marrow stromal cells. $N$ Engl $J$ Med 2001; 344(5): 385-386, https://doi.org/10.1056/ nejm200102013440516.

122. Marcacci M., Kon E., Moukhachev V., Lavroukov A., Kutepov S., Quarto R., Mastrogiacomo M., Cancedda R. Stem cells associated with macroporous bioceramics for long bone repair: 6- to 7-year outcome of a pilot clinical study. Tissue Eng 2007; 13(5): 947-955, https://doi.org/10.1089/ten.2006.0271

123. Tolar J., Nauta A.J., Osborn M.J., Panoskaltsis Mortari A., McElmurry R.T., Bell S., Xia L., Zhou N., 
Riddle M., Schroeder T.M., Westendorf J.J., Mclvor R.S., Hogendoorn P.C., Szuhai K., Oseth L., Hirsch B., Yant S.R., Kay M.A., Peister A., Prockop D.J., Fibbe W.E., Blazar B.R. Sarcoma derived from cultured mesenchymal stem cells. Stem Cells 2007; 25(2): 371-379, https://doi.org/10.1634/ stemcells.2005-0620.

124. Tasso R., Augello A., Carida' M., Postiglione F., Tibiletti M.G., Bernasconi B., Astigiano S., Fais F., Truini M., Cancedda R., Pennesi G. Development of sarcomas in mice implanted with mesenchymal stem cells seeded onto bioscaffolds. Carcinogenesis 2009; 30(1): 150-157, https://doi. org/10.1093/carcin/bgn234.

125. Hustedt J.W., Jegede K.A., Badrinath R., Bohl D.D., Blizzard D.J., Grauer J.N. Optimal aspiration volume of vertebral bone marrow for use in spinal fusion. Spine J 2013; 13(10): 1217-1222, https://doi.org/10.1016/j. spinee.2013.07.435.

126. Liu H.C., E L.L., Wang D.S., Su F., Wu X., Shi Z.P., Lv Y., Wang J.Z. Reconstruction of alveolar bone defects using bone morphogenetic protein 2 mediated rabbit dental pulp stem cells seeded on nano-hydroxyapatite/collagen/poly(Llactide). Tissue Eng Part A 2011; 17(19-20): 2417-2433, https://doi.org/10.1089/ten.tea.2010.0620.

127. Lavery K., Swain P., Falb D., Alaoui-Ismaili M.H. BMP-2/4 and BMP-6/7 differentially utilize cell surface receptors to induce osteoblastic differentiation of human bone marrow-derived mesenchymal stem cells. J Biol Chem 2008; 283(30): 20948-20958, https://doi.org/10.1074/jbc. m800850200.

128. Egermann M., Lill C.A., Griesbeck K., Evans C.H., Robbins P.D., Schneider E., Baltzer A.W. Effect of BMP-2 gene transfer on bone healing in sheep. Gene Ther 2006; 13(17): 1290-1299, https://doi.org/10.1038/sj.gt.3302785.

129. Lee S.S., Huang B.J., Kaltz S.R., Sur S., Newcomb C.J., Stock S.R., Shah R.N., Stupp S.I. Bone regeneration with low dose BMP-2 amplified by biomimetic supramolecular nanofibers within collagen scaffolds. Biomaterials 2013, 34(2): 452-459, https://doi.org/10.1016/j. biomaterials.2012.10.005.

130. Yang F., Wang J., Hou J., Guo H., Liu C. Bone regeneration using cell-mediated responsive degradable PEGbased scaffolds incorporating with rhBMP-2. Biomaterials 2013; 34(5): 1514-1528, https://doi.org/10.1016/j. biomaterials.2012.10.058.

131. Cha J.K., Lee J.S., Kim M.S., Choi S.H., Cho K.S., Jung U.W. Sinus augmentation using BMP-2 in a bovine hydroxyapatite/collagen carrier in dogs. J Clin Periodontol 2014; 41(1): 86-93, https://doi.org/10.1111/jcpe.12174.

132. Jang J.W., Yun J.H., Lee K.I., Jang J.W., Jung U.W., Kim C.S., Choi S.H., Cho K.S. Osteoinductive activity of biphasic calcium phosphate with different rhBMP-2 doses in rats. Oral Surg Oral Med Oral Pathol Oral Radiol 2012; 113(4): 480-487, https://doi.org/10.1016/j.tripleo.2011.04.013.

133. Schwender J.D., Holly L., Rouben D.P., Foley K.T. Minimally invasive transforaminal lumbar interbody fusion (TLIF): technical feasibility and initial results. J Spinal Disord Tech 2005; 18(S1): S1-S6, https://doi.org/10.1097/01. bsd.0000132291.50455.d0.

134. Lewandrowski K.U., Nanson C., Calderon R. Vertebral osteolysis after posterior interbody lumbar fusion with recombinant human bone morphogenetic protein 2: a report of five cases. Spine J 2007; 7(5): 609-614, https://doi. org/10.1016/j.spinee.2007.01.011.
135. Shields L.B., Raque G.H., Glassman S.D., Campbell M., Vitaz T., Harpring J., Shields C.B. Adverse effects associated with high-dose recombinant human bone morphogenetic protein-2 use in anterior cervical spine fusion. Spine 2006; 31(5): 542-547, https://doi.org/10.1097/01. brs.0000201424.27509.72.

136. Vaidya R., Weir R., Sethi A., Meisterling S., Hakeos W., Wybo C.D. Interbody fusion with allograft and rhBMP-2 leads to consistent fusion but early subsidence. $J$ Bone Joint Surg Br 2007; 89(3): 342-345, https://doi. org/10.1302/0301-620x.89b3.18270.

137. Mesfin A., Buchowski J.M., Zebala L.P., Bakhsh W.R., Aronson A.B., Fogelson J.L., Hershman S., Kim H.J., Ahmad A., Bridwell K.H. High-dose rhBMP-2 for adults: major and minor complications: a study of 502 spine cases. J Bone Joint Surg Am 2013; 95(17): 1546-1553, https://doi. org/10.2106/jbjs.I.01730.

138. Moshel Y.A., Hernandez E.I., Kong L., Liu C., Samadani U. Acute renal insufficiency, supraventricular tachycardia, and confusion after recombinant human bone morphogenetic protein-2 implantation for lumbosacral spine fusion. J Neurosurg Spine 2008; 8(6): 589-593, https://doi. org/10.3171/spi/2008/8/6/589.

139. Fu R., Selph S., McDonagh M., Peterson K., Tiwari A., Chou R., Helfand M. Effectiveness and harms of recombinant human bone morphogenetic protein-2 in spine fusion: a systematic review and meta-analysis. Ann Intern Med 2013; 158(12): 890-902, https://doi.org/10.7326/0003-4819158-12-201306180-00006.

140. Guo X., Zheng Q., Kulbatski I., Yuan Q., Yang S., Shao Z., Wang H., Xiao B., Pan Z., Tang S. Bone regeneration with active angiogenesis by basic fibroblast growth factor gene transfected mesenchymal stem cells seeded on porous beta-TCP ceramic scaffolds. Biomed Mater 2006; 1(3): 93-99, https://doi.org/10.1088/1748-6041/1/3/001.

141. Maehara H., Sotome S., Yoshii T., Torigoe I., Kawasaki Y., Sugata Y., Yuasa M., Hirano M., Mochizuki N., Kikuchi M., Shinomiya K., Okawa A. Repair of large osteochondral defects in rabbits using porous hydroxyapatite/ collagen $(\mathrm{HAp} / \mathrm{Col})$ and fibroblast growth factor-2 (FGF-2). J Orthop Res 2010; 28(5): 677-686, https://doi.org/10.1002/ jor.21032.

142. Hollinger J.O., Hart C.E., Hirsch S.N., Lynch S., Friedlaender G.E. Recombinant human platelet-derived growth factor: biology and clinical applications. J Bone Joint Surg Am 2008; 90(Suppl 1): 48-54, https://doi.org/10.2106/ jbjs.g.01231.

143. Lieberman J.R., Daluiski A., Einhorn T.A. The role of growth factors in the repair of bone. Biology and clinical applications. J Bone Joint Surg Am 2002; 84(6): 1032-1044, https://doi.org/10.2106/00004623-200206000-00022.

144. Graham S., Leonidou A., Lester M., Heliotis M., Mantalaris A., Tsiridis E. Investigating the role of PDGF as a potential drug therapy in bone formation and fracture healing. Expert Opin Investig Drugs 2009; 18(11): 1633-1654, https:// doi.org/10.1517/13543780903241607.

145. Luvizuto E.R., Tangl S., Dobsak T., Reich K., Gruber R., Sonoda C.K., Okamoto R. Effect of recombinant PDGF-BB on bone formation in the presence of $\beta$-tricalcium phosphate and bovine bone mineral matrix: a pilot study in rat calvarial defects. BMC Oral Health 2016; 16(1): 52, https://doi. org/10.1186/s12903-016-0210-3.

146. Zhao L., Jiang S., Hantash B.M. Transforming growth 
factor $\beta 1$ induces osteogenic differentiation of murine bone marrow stromal cells. Tissue Eng Part A 2010; 16(2): 725-733, https://doi.org/10.1089/ten.tea.2009.0495.

147. Kwok S., Partridge N.C., Srinivasan N., Nair S.V., Selvamurugan N. Mitogen-activated protein kinase-dependent inhibition of osteocalcin gene expression by transforming growth factor- $\beta 1$. J Cell Biochem 2009; 106(1): 161-169, https://doi.org/10.1002/jcb.21991.

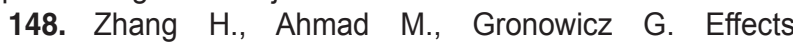
of transforming growth factor- $\beta 1$ (TGF- $\beta 1$ ) on in vitro mineralization of human osteoblasts on implant materials. Biomaterials 2003; 24(12): 2013-2020, https://doi.org/10.1016/ s0142-9612(02)00616-6.

149. Alliston T., Choy L., Ducy P., Karsenty G., Derynck R. TGF- $\beta$-induced repression of CBFA 1 by Smad3 decreases cbfa1 and osteocalcin expression and inhibits osteoblast differentiation. EMBO J 2001; 20(9): 2254-2272, https://doi. org/10.1093/emboj/20.9.2254.

150. Kaji H., Naito J., Sowa H., Sugimoto T., Chihara K. Smad3 differently affects osteoblast differentiation depending upon its differentiation stage. Horm Metab Res 2006: 38(11): 740-745, https://doi.org/10.1055/s-2006-955085.

151. Centrella M., Ji C., Casinghino S., McCarthy T.L. Rapid flux in transforming growth factor- $\beta$ receptors on bone cells. J Biol Chem 1996; 271(31): 18616-18622, https://doi. org/10.1074/jbc.271.31.18616.

152. Ochiai H., Yamamoto Y., Yokoyama A., Yamashita H., Matsuzaka K., Abe S., Azuma T. Dual nature of TGF- $\beta 1$ in osteoblastic differentiation of human periodontal ligament cells. J Hard Tissue Biol 2010; 19(3): 187-191, https://doi. org/10.2485/jhtb.19.187.

153. Ochiai H., Okada S., Saito A., Hoshi K., Yamashita H., Takato T., Azuma T. Inhibition of insulin-like growth factor-1 (IGF-1) expression by prolonged transforming growth factor- $\beta 1$ (TGF- $\beta 1$ ) administration suppresses osteoblast differentiation. J Biol Chem 2012; 287(27): 22654-22661, https://doi. org/10.1074/jbc.m111.279091.

154. Lau K.H., Kapur S., Kesavan C., Baylink D.J. Upregulation of the Wnt, estrogen receptor, insulin-like growth factor-I, and bone morphogenetic protein pathways in C57BL/6J osteoblasts as opposed to $\mathrm{C} 3 \mathrm{H} / \mathrm{HeJ}$ osteoblasts in part contributes to the differential anabolic response to fluid shear. J Biol Chem 2006; 281(14): 9576-9588, https://doi. org/10.1074/jbc.M509205200.

155. Lean J.M., Mackay A.G., Chow J.W., Chambers T.J. Osteocytic expression of mRNA for c-fos and IGF-I: an immediate early gene response to an osteogenic stimulus. $\mathrm{Am}$ J Rhysiol 1996; 270(6 Pt1): 937-945, https://doi.org/10.1152/ ajpendo.1996.270.6.e937

156. Kawata A., Mikuni-Takagaki Y. Mechanotransduction in stretched osteocytes - temporal expression of immediate early and other genes. Biochem Biophys Res Commun 1998; 246(2): 404-408, https://doi.org/10.1006/bbrc.1998. 8632.

157. Reijnders C.M. Bravenboer N. Tromp A.M., Blankenstein M.A., Lips P. Effect of mechanical loading on insulin-like growth factor-l gene expression in rat tibia. J Endocrinol 2007: 192(1): 131-140, https://doi.org/10.1677/ joe.1.06880.

158. Sakata T., Wang Y., Halloran B.P., Elalieh H.Z., Cao J., Bikle D.D. Skeletal unloading induces resistance to insulin-like growth factor-I (IGF-I) by inhibiting activation of the IGF-I signaling pathways. J Bone Miner Res 2004; 19(3): 436446, https://doi.org/10.1359/jbmr.0301241.

159. Kesavan C., Wergedal J.E., Lau K.H., Mohan S. Conditional disruption of IGF-I gene in type 1alpha collagenexpressing cells shows an essential role of IGF-I in skeletal anabolic response to loading. Am J Physiol Endocrinol Metab 2011; 301(6): E1191-E1197, https://doi.org/10.1152/ ajpendo.00440.2011.

160. Sheng M.H., Lau K.H., Baylink D.J. Role of osteocyte-derived insulin-like growth factor $\mathrm{i}$ in developmental growth, modeling, remodeling, and regeneration of the bone. J Bone Metab 2014; 21(1): 41-54, https://doi.org/10.11005/ jbm.2014.21.1.41.

161. Geiger F., Lorenz H., Xu W., Szalay K., Kasten P., Claes L., Augat P., Richter W. VEGF producing bone marrow stromal cells (BMSC) enhance vascularization and resorption of a natural coral bone substitute. Bone 2007; 41(4): 516-522, https://doi.org/10.1016/j.bone.2007.06.018.

162. Wernike E., Montjovent M.O., Liu Y., Wismeijer D., Hunziker E.B., Siebenrock K.A., Hofstetter W., Klenke F. VEGF incorporated into calcium phosphate ceramics promotes vascularisation and bone formation in vivo. Eur Cell Mater 2010; 19: 30-40, https://doi.org/10.22203/ecm. v019a04.

163. Maes C., Coenegrachts L., Stockmans I., Daci E., Luttun A., Petryk A., Gopalakrishnan R., Moermans K., Smets N., Verfaillie C., Carmeliet P., Bouillon R., Carmeliet G. Placental growth factor mediates mesenchymal cell development, cartilage turnover, and bone remodeling during fracture repair. J Clin Invest 2006; 116(5): 1230-1242, https:// doi.org/10.1172/jci26772.

164. McCoy R.J., Widaa A., Watters K.M., Wuerstle M., Stallings R.L., Duffy G.P., O'Brien F.J. Orchestrating osteogenic differentiation of mesenchymal stem cells - identification of placental growth factor as a mechanosensitive gene with a proosteogenic role. Stem Cells 2013; 31(11): 2420-2431, https:// doi.org/10.1002/stem.1482.

165. Liu Y., Deng L.Z., Sun H.P., Xu J.Y., Li Y.M., Xie X., Zhang L.M., Deng F.L. Sustained dual release of placental growth factor-2 and bone morphogenic protein-2 from heparin-based nanocomplexes for direct osteogenesis. Int $\mathrm{J}$ Nanomedicine 2016; 11: 1147-1158, https://doi.org/10.2147/ ijn.s100156.

166. Kadam A., Millhouse P.W., Kepler C.K., Radcliff K.E., Fehlings M.G., Janssen M.E., Sasso R.C., Benedict J.J., Vaccaro A.R. Bone substitutes and expanders in spine surgery: a review of their fusion efficacies. Int J Spine Surg 2016; 10 : 33, https://doi.org/10.14444/3033.

167. Ghassemi T., Shahroodi A., Ebrahimzadeh M.H., Mousavian A., Movaffagh J., Moradi A. Current concepts in scaffolding for bone tissue engineering. Arch Bone Jt Surg 2018; 6(2): 90-99.

168. Chen W., Liu X., Chen Q., Bao C., Zhao L., Zhu Z., $\mathrm{Xu}$ H.H.K. Angiogenic and osteogenic regeneration in rats via calcium phosphate scaffold and endothelial cell co-culture with human bone marrow mesenchymal stem cells (MSCs), human umbilical cord MSCs, human induced pluripotent stem cellderived MSCs and human embryonic stem cell-derived MSCs. $J$ Tissue Eng Regen Med 2018; 12(1): 191-203, https://doi. org/10.1002/term.2395. 